\title{
THE INFLUENCE OF EMOTIONAL FACTORS, MATERIALISM, RISK PERCEPTION, AND FINANCIAL LITERACY ON THE TENDENCY OF DEBT OF MILLENNIAL GENERATION IN SURABAYA
}

\author{
Richard Widjaja ${ }^{1}$, Dewi Pertiwi ${ }^{2}$ \\ 1,2 Finance and Investment Program \\ Faculty of Business and Economics, Petra Christian University \\ Jl. Siwalankerto 121-131, Surabaya \\ E-mail: 137416006@john.petra.ac.id; ²dewi.pertiwi@petra.ac.id
}

\begin{abstract}
This study aims to determine the effect of emotion, materialism, risk perception, and financial literacy on the propensity toward indebtedness of the millennial generation in Surabaya. The researcher uses a online questionnaire distributed via Google Form to 110 millennials in Surabaya. The collected data is processed using Partial Least Square (PLS). This study indicates that emotion, materialism, and perceptions have a significant effect on indebtedness propensity.
\end{abstract}

Keywords: Emotions, Financial Literacy, Propensity Debt, Materialism, Perceptions of Risk.

\section{INTRODUCTION}

According to BPS data (2016), Indonesia is entering an era of demographic bonuses or an explosion of a very productive population. Positively, the excess of the very productive age population (67.9\% of Indonesians) can be used to increase development, and $40 \%$ of people in Indonesia are the millennial generation. Quoting from Rudhiwantoro's research (2018), the millennial generation was born during the development of advanced technology, which certainly affects this millennial generation's habits and perspectives. The millennial generation is very synonymous with gadgets and the internet. The presence of the Indonesian millennial generation is a blessing for the country, to be directly involved in stimulating the technology-based creative industry. Therefore, the millennial generation is a generation that is quite familiar with the development of information technology.

The good thing about digital culture and the use of the internet is that the movement of millennial generation is becoming faster. Making transactions through the internet can remove many of the obstacles that may arise with physical purchases. However, it might increase the ill effects of consumption behavior. According to the data retrieved from Lokadata (2017), Surabaya is the city with the highest percentage of online shopping, that is as many as $71 \%$ of several cities in Indonesia such as Medan, $68 \%$ and Jakarta $66 \%$ and $50 \%$ of online shoppers are millennial generation (Tashandra, 2018).

The behavior of the indebtness tendency for the consumptive interests of the millennial generation is essential to discuss because one of the characteristics of the millennial generation is that this generation has strong purchasing power (Rudhiwantoro, 2018). In Indonesia, not only millennials from ordinary people, but millennials from the upper class are also said to be in debt because of their bourgeois style, which often spends money to fulfill their lifestyle (Supriyatna, 2019). The millennial generation's income is enough to meet a month's needs and can be set aside for investing. Still, because they have installments or debt for consumptive purposes, the millennials aren't able to invest (Rahayu, 2019).

Table 1. Debt Level Data in Surabaya

\begin{tabular}{lc}
\hline Year & Consumptive Payable \\
\hline 2015 & $458,682,875$ \\
2016 & $600,411,985$ \\
Percentage of Increase & $30.90 \%$ \\
\hline
\end{tabular}


Consumptive debt is debt that aims to meet the needs of borrowers, while productive debt is debt for working capital and investment (Setiawan, S, 2020). Research conducted by the IDN Research Institute (2019) found that around 63 million people in Indonesia are millennials. Only $35.1 \%$ own a house, and the rest don't, if millennials only think about what they want now to go into debt when millennials can have enough money to meet more important needs such as a house. Based on data from the City of Surabaya Finance (2018), it is found that there has been an increase in the level of loans or debt from commercial banks and BPRs, and the debt is used for consumption.

Vitt (2004) states that credit problems are not only influenced by economic factors but also psychological factors. Credit should help people to improve their financial condition by making it possible to acquire assets, covering essential expenses that go on in the long term (Kurniawan et al., 2020). But in reality, the supply of credit makes people misuse and tends to be more indebted for consumptive purposes. Vitt (2004) states that credit problems are influenced by economic factors and are also influenced by psychological factors. Credit should help people to improve their financial condition by making it possible to acquire assets, covering essential expenses that go on in the long term. But in reality, the supply of credit makes people misuse and tends to be more indebted for consumptive purposes. This study will examine whether the risk perception factors, financial literacy, emotions, and materialism affect the tendency to owe the millennial generation in Surabaya.

\section{LITERATURE REVIEW}

Theory of Planned Behavior (TPB) is a theory that measures or predicts a person's behavior balanced to carry out the behavior. TPB is developing the theory of reasoned action (TRA) by lcek Ajzen and Martin Fishbein in 1985. TRA states that carrying out behavior is motivated by individual intentions, influenced by two factors: attitude and subjective norms.

After several years of mapping analysis of TRA, Ajzen (1991) concluded that TRA only applies to behavior under the control of an individual but does not apply to conduct that is not under that individual's control. Therefore, Ajzen and Fishbein add one factor that can influence behavior intention, namely perceived behavioral control. These additions caused Ajzen and Fishbein to change Theory of Reasoned Action (TRA) into Theory of Planned Behavior (TPB).

Debt behavior has a relationship with intention. This shows that intention is the closest factor that can predict the emergence of a person's behavior. Theory planned behavior (TPB), proposed by Ajzen (1991), is known as a person's behavior can be predicted through intention, where the intention is influenced by attitudes toward behavior, subjective norms, and perceived behavior control. The theory of planned behavior revealed that a person's intention very much determines a person's decision to behave in debt. Attitude is one of the critical reasons to intend to do something. This has been proven by finding a relationship between attitude and debt intention (Brown, Taylor \& Price, 2005).

The basis of debt behavior is using planned behavior theory. According to the Big Indonesian Dictionary (KBBI) (1988), debt is money borrowed from other people, and those who borrow must pay back what has been received. Being in debt itself means having a debt to someone. The word 'tends to be' in the Big Indonesian Dictionary (KBBI) is to have interest, for example, desire, while tendency according to $\mathrm{KBBI}$ is to be sad; desire (liking) for something, thus it can be interpreted that the tendency to be in debt is the willingness to have an obligation to someone.

According to KBBI (1988), emotion is an overflow of feelings that develop and recede in a short time or psychological and physiological conditions and reactions (such as joy, sadness, compassion, love). This emotional factor is related to an individual's ability to express emotions (positive or negative) when handling financial decisions. In the sense of this classification that this study uses emotions, considering how indebted society affects personal problems, such as shame, pride, and nervousness, which are emotions that tend toward debt. 
Richins and Dawson (1992) state that materialism is defined as the importance of ownership and acquisition of material goods to achieve a desired life goal or state. Materialism can also be defined as a person who seeks wealth to increase social status and increase pleasure. Santos \& Fernandes (2011) also said that people are materialistic if they do something to seek excessive status, such as wanting to be seen because they have high-value goods.

Perceived risk shows how individuals view risk during decision-making (Caetano, 2011). For example, two people who will buy the same item can feel the risk differently when purchasing the same thing. Barros and Botelho (2012) state that they will make different decisions regarding these items. Garling's research (2009); Keese, (2012); Doosti \& Karampour (2017) previously linked risk perceptions with financial decision making, for example, making investments, making loans.

According to the Financial Services Authority (OJK, 2016), financial literacy is a combination of knowledge, skills, and beliefs that influence attitudes and behavior to improve decision-making and financial management quality to achieve financial prosperity. Financial literacy is critical in determining the success of future generations. This is because financial literacy will show a person's ability to make judgments based on information obtained in taking effective actions regarding the use and management of money in the present and the future (Gabriel \& Linawati, 2020).

Generation $Y$ or also known as the "Millennial Generation" and "Echo Boomers" is a generation born between 1980 and 2000 (Naumovska, 2017). Generation $Y$ is described as a generation that is educated, intelligent in technology, experienced in all things, mature, and structured (B. Valentine \& L Powers, 2013).

\section{The Influence of Emotions on Debt Tendency}

Ottaviani and Vandone (2010) state that emotional responses are considered to be a major factor in financial decision-making. Muzafari, Mowlaie \& Bahmani (2016) found in their research that individuals who have debt have negative emotions and that negative emotions tend to have a high level of risk, causing individual desire to encourage unplanned expenditure and lead to debt. However, contrary to research conducted by Quelch and Jocz, 2007, it is said that positive emotions such as joy and satisfaction are what make individuals more likely to get into debt.

\section{The Effect of Materialism on Debt Tendency}

Previous research has linked materialism to behavior related to consumption (Ponchio, 2006; Flores and Vieira, 2014). Santos \& Fernandes (2011) said that people are materialistic if they do something to seek excessive status, such as wanting to be seen because they have high-valued goods. Ponchio (2006) found that more materialistic people tend to have higher levels of debt.

\section{The Effect of Perceptions of Risk on Tendency to Be in Debt}

Risk perceptions of affecting the tendency to become indebted can be proven from the research results of Caetano et al. (2011), who found that people with high-risk perceptions tend to have low debt levels. Researcher Olsen (2009) said that risk perception is fear oriented. Perceived risk can be experienced by many people, triggered by fear of potential loss. Losses can be in the form of money, reputation, or even temporarily pending, such as regret.

\section{The Effect of Financial Literacy on Debt Tendency}

Luhrmann (2014) shows that a lack of financial knowledge causes individuals to make wrong financial decisions, namely going into debt for consumptive purposes. French \& McKillop (2016) states that financial literacy helps people to be ready to manage personal finances. For example, financially literate individuals can set financial goals, spend within individual budgets and pay credits on time to avoid late payment fees. 


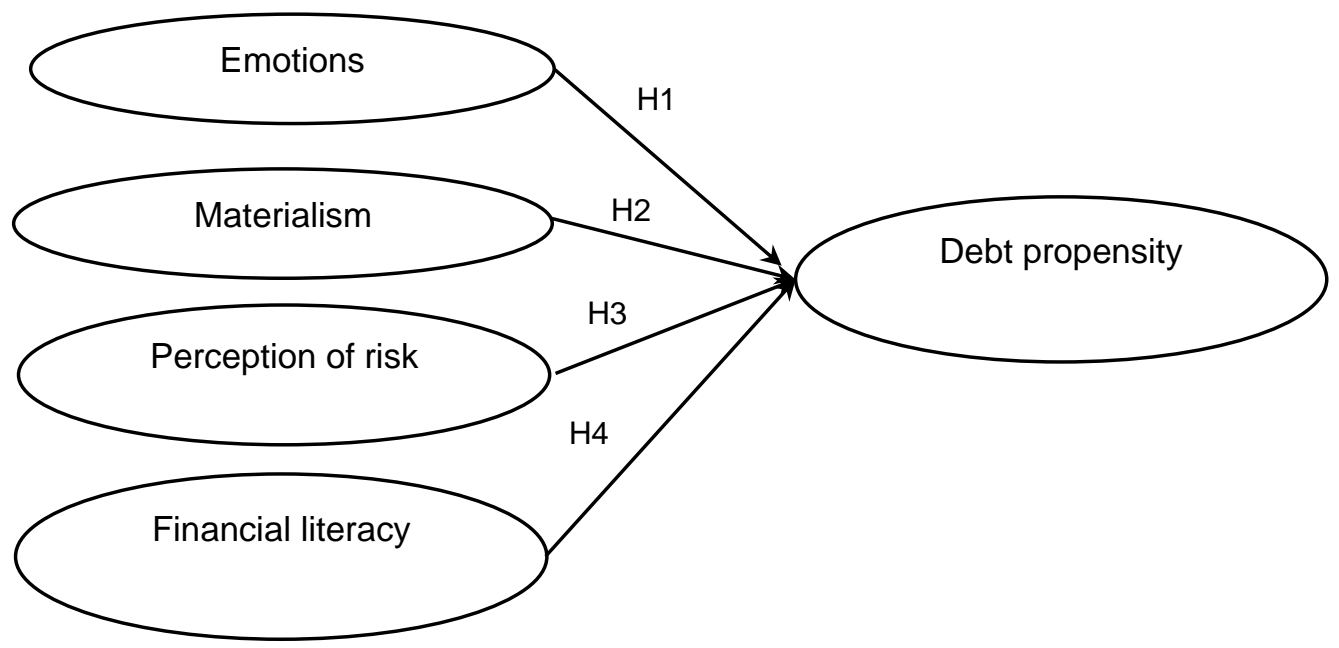

Figure 1. Thinking Framework

Based on the above framework, the hypothesis of this study is:

$\mathrm{H} 1$ : Emotions have a significant effect on debt tendencies.

$\mathrm{H} 2$ : Materialism has a significant effect on debt propensity.

H3: Perception of risk is have a significant impact on debt propensity.

$\mathrm{H} 4$ : Financial literacy have a significant impact on debt tendencies.

\section{METHODOLOGY}

The type of research is a type of associative research using a quantitative approach. A quantitative approach is a scientific approach that can be classified, concrete, observable,measurable. The relationship between variables is causal where the research data is in the form of numbers, and the analysis uses statistics.

\section{Population and Sample}

The population is all data that has been determined by the researcher within a specific scope and time. In this study, the population to be studied was the people of Surabaya, totaling $2,904,751$ people from BPS (2020). This study uses a sampling technique, namely incidental sampling, which is included in the non-probability sampling technique. The sample in this study is the millennial generation of Surabaya. In 2020, the millennial generation was people aged 20-40 years. By using the Slovin formula, the minimum number of samples is 100 respondents.

\section{Types and Sources of Data}

The data used in this study are primary data. In this study, the preliminary data comes from online questionnaires that have been distributed to respondents using Google Form (Kurniawan et al., 2020).

\section{Data Collection Methods and Procedures}

The data collection method used in this study was using a questionnaire. In this case, the researcher distributes questionnaires to respondents by distributing questionnaires online using Google Form.

\section{Data Analysis Techniques}

The Structural Equation Modeling (SEM) approach is an approach used in this study by using a path diagram that allows entering all observed variables following the related theoretical model. Testing the research hypothesis, namely, the effect of exogenous latent variables on endogenous 
latent variables is based on the t-statistic value, where the impact is significant if the t-statistic value is above 1.96 .

$\mathrm{H}_{0}: \beta$ emotion $=0$, emotion has no effect significant on the tendency to become indebted

$\mathrm{H}_{1}$ : $\beta$ emotion $\neq 0$, emotion has a significant effect on the tendency to become indebted.

$\mathrm{H}_{0}: \beta$ materialism $=0$, materialism has no significant effect on the tendency to become indebted

$\mathrm{H}_{1}: \beta$ materialism $\neq 0$, materialism affects significantly towards the tendency to be indebted.

$\mathrm{H}_{0}: \beta$ risk perception $=0$, risk perception does not have a significant effect on the tendency to become indebted

$\mathrm{H}_{1}: \beta$ risk perception $\neq 0$, risk perception has affected significant the tendency to become indebted.

$\mathrm{H}_{0}: \quad \beta$ financial literacy $=0$, financial literacy has no significant effect on the tendency for owing

$\mathrm{H}_{1}$ : $\beta$ financial literacy $\neq 0$, financial literacy has a significant effect on going into debt.

\section{ANALYSIS AND DISCUSSION}

Based on the results of the data processing that has been done, the results of the research are as follows:

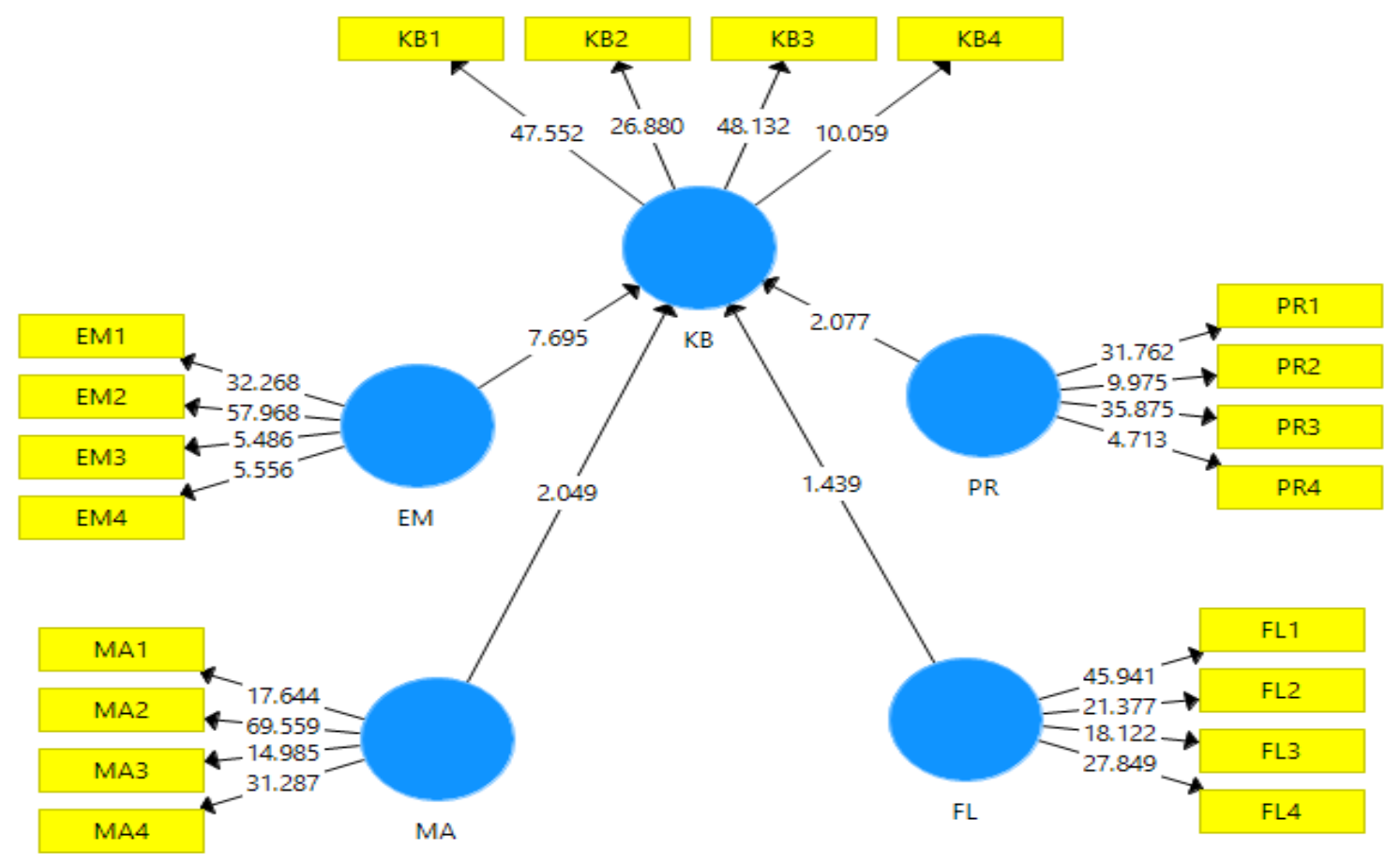

Figure 2. Diagram of Boostrapping Results

\section{The Influence of Emotions on the Tendency of Millennials in Surabaya}

The results of research that has been conducted show that emotions have a significant effect on the tendency to owe in millennial generation in Surabaya. This is because emotions cause positive or negative feelings when in debt to affect the decision to owe or not (Flores \& Vieira, 2014).

Based on the emotions of respondents who tend to go into debt, it shows that respondents who have positive emotions tend to be in debt. This is supported by the highest mean indicator where respondents feel they do not cause conflict if they are in debt for consumptive purposes with their friends. Quelch \& Jocz (2007) state that if the individual is happy with the goods or something desired, the individual will look for ways to get the goods and one of them is by making a wrong financial decision through debt. This research is in line with the study of Selvaraja \& Abdullah (2019), which found that when a person experiences negative emotional experiences (namely, nervousness, depression, and anxiety) because of having a debt obligation, the person will find a 
way to reduce the debt. In this study, respondents have not felt negative emotions, so that they do not look for ways to reduce the tendency to go into debt.

\section{The Effect of Materialism on the Tendency of Debt of Millennial Generations in Surabaya}

The results of research that has been done show that materialism has a significant effect on the tendency to be in debt. Based on this research, the high level of materialism makes individuals tend to be in debt. The results of this study are in line with the research of Azma, N (2019), which states that individuals who highly value the ownership of an item should be considered because such individuals are individuals who have a high tendency to go into debt. The results of this study are also in line with Ponchio's (2006) study, which found that more materialistic people tend to have higher levels of debt.

\section{The Effect of Risk Perceptions on the Tendency of Debt for Millennial Generation in Surabaya}

The research results show that the perception of risk has a significant effect on the tendency to be in debt. Based on this research, individuals who have low-risk perceptions tend to be in debt because these individuals do not think about the high risk of being in debt so that the individual is in debt. The results of this study are in line with research by Olsen, R (2009), which states that people who be afraid tend to have a high-risk perception, so they do not go into debt. Other research, namely from Rahman, Azma, Masud, \& Ismail (2019) and Gabriel \& Linawati, (2020). said that the level of debt the person has is low if the risk perception is higher.

\section{The Influence of Financial Literacy on the Tendency of Debt for Millennial Generation in Surabaya}

The research results show that financial literacy does not affect the tendency to be in debt. Based on this study, individuals with high or low financial literacy do not affect the tendency to go into debt because they are still in debt even though they have high or low financial literacy. Financial literacy will make people understand that debt is not a good thing, but people tend to take advantage of the ease of credit/debit nowadays. This study is in line with Sevim et al. (2012); French and McKillop (2016) state that financial literacy helps people to get ready to manage their personal finances so that the person remains in debt. This research is also in line with research by Flores \& Vieira (2014), which states that financial literacy does not affect debt tendencies.

\section{CONCLUSIONS AND RECOMMENDATIONS}

Based on the results of the analysis and discussion, emotion, materialism, and risk perception significantly affect the tendency of indebtedness of the millennial generation in Surabaya. However, financial literacy does not significantly affect the tendency to owe the millennial generation in Surabaya. Suggestions that can convey are as follows:

1) It is better for the community, especially the millennial generation, to control more emotions, increase risk perceptions and lower materialism to avoid the tendency to go into debt.

2) For future researchers, it is hoped that they will distinguish between millennial generations who are already working. Those who have not worked so that there can be seen the differences between millennial generations who are already income and those who are not yet income due to the level of tendencies to have debt.

\section{REFERENCES}

Ahmed, UZ, Ismail, I., Sadiq Sohail, M., \& Tabsh, I. (2010). Malaysian consumers' credit card usage behavior. Asia Pacific Journal of Marketing and Logistics, 528-544.

Ajzen, I. (2005). Attitudes, personality, and behavior. New York: Two Penn Plaza.

Arikunto. (2013). Research procedure: A practical approach. Jakarta: Rineka Cipta. 
Astuti, P. (2019, September 21). Serem, 40\% of Indonesian Millennials are in Debt! Retrieved from Answers.com: https://www.awaban.com/read/article/id/2019/09/21/3/190923165228/ serem40 milenial_indonesia_terl ilit_hutangini_yang_harus_kamu_k tahu_untuk_m overcome

Barros, L., \& Botelho, D. (2012). Hope, perceived financial risk and propensity for indebtedness. BAR - Brazilian Administration Review, 454-474.

BPS. (2016, September 6). Indonesia Entered the Era of Demographic Bonus. Retrieved from databoks.katadata.co.id: https://databoks.katadata.co.id/datapublish/2016/09/06/indonesiaentering-bonus-demographic-era-peak-occurs-in-2025-2030

BPS. (2019). Projections of Population in Surabaya City by Gender and Age Group in 2019. Retrieved from Surabaya Kota.bps.go.id: https://surabayakota.bps.go.id/dynamictable/2018/0 4/18/23 projection-population- Kota-Surabaya-by-sex-and-age-group-year-2019.html

Bruce, D. (2007, December 13). The chairman is frustrated by 'nonsense'. Otago Daily Times. Retrieved from http://www.odt.co.nz

Caetano, G., Palacios, M., \& Patrios, HA (2011). Measuring aversion to debt: experiments among student loan candidates. Retrieved from Policy Research Working Paper: http://documents. worldbank.org/curated/en/875171468183545929 / Measuring-aversion-to-debt-an-experimentamong-student-loan-candidates

Cakarnis, J., \& D' Alessandro, SP (2015). Does knowing overcome wanting? The impact of consumer knowledge and materialism upon credit card selection with young consumers. Young Consumers, 50-70.

Collette, R.L. (1990). Harvesting techniques. In RE Martin \& GJ Flick (Eds.), The seafood industry, 471-526, New York: Van Nostrand Reinhold.

Davies, E., \& Lea, S., (1995). Student attitudes to student debt. Journal of Economic Psychology, 663-679.

Disney, R., \& Gathergood, J. (2011). Financial literacy and indebtedness: new evidence for UK consumers. Retrieved from EconPapers: http://econpapers.repec.org/paper/notnotcfc/11_2f05

Disney, R., \& Gathergood, J. (2013). Financial literacy and consumer credit portfolios. Journal of Banking and Finance, 2246-2254.

Doosti, BA, \& Karampour, A. (2017). The impact of behavioral factors on propensity toward indebtedness case study: indebted customers of Maskan Bank, Tehran province (geographic regions: east). Journal of Advances in Computer Engineering and Technology, 21-30.

Flores, SM, \& Vieira, KM (2014). Propensity toward indebtedness: an analysis using behavioral factors. Journal of Behavioral and Experimental Finance, 1-10.

French, D., \& McKillop, D. (2016). Financial literacy and over-indebtedness in low-income households. International Review of Financial Analysis, 1-11.

Gabriel, F., \& Linawati, N. (2020). Pengaruh financial capability, money attitudes, dan socioeconomic status terhadap adverse financial events. International Journal of Financial and Investment Studies (IJFIS), 1(1), 15-20. https://doi.org/10.9744/ijfis.1.1.15-20

Gardarsdottir, RB, \& Dittmar, H. (2012). The relationship of materialism to debt and financial wellbeing: The case of Iceland's perceived prosperity. Journal of Economic Psychology, 471-481.

Garling, T., Kirchler, E., Lewis, A., \& Raaij, F.V. (2009). Psychology, financial decision making, and financial crises. Psychological Science in the Public Interest, 1-47.

Gathergood, \& Gathergood, J. (2012). Self-control, financial literacy and consumer overindebtedness. Journal of Economic Psychology, 590-602.

Ghozali, I. (2011). Multivariate Analysis Application with the IBM SPSS 19 Program. Semarang: Diponegoro University Publishing Agency.

Hong-Van, T., Phanuphak, N., Ananworanich, J., Vatanparast, R., Jadwattanakul, T., Pharachetsakul, N., Phanuphak, P. (2010). Acceptability of male circumcision for the prevention of HIV among high-risk heterosexual men in Thailand. Sexually Transmitted Diseases, 37(6), 352-355.

Indonesia Financial Inclusion Insight Survey. (2017, 5). Retrieved from Finclusion: http://finclusion.org/uploads/file/technical_report_indonesia_fii_iv_final.pdf

Kaufman, C., Perlman, R., \& Speciner, M. (1995). Network security: private communication in a public world. Englewood Cliffs, NJ: Prentice-Hall. 
Kamleitner, B., Hornug, B., \& Kirchler, E. (2011). Over-indebtedness and the interplay of factual and mental money management: an interview study. New Zealand Economic Papers, 139160.

Keese, M. (2012). Who feels constrained by high debt burdens? Subjective vs. objective measures of household debt. Journal of Economic Psychology, 125-141.

Kurniawan. J. Y., Malelak, M. I., \& Astuti, D. (2020). Pengaruh attitude, subjective norm, past behavior, dan perceived control terhadap budgeting intention mahasiswa di Surabaya. International Journal of Financial and Investment Studies (IJFIS), 1(1), 21-29. https://doi.org/10.9744/ijfis.1.1.21-29

Livingstone, SM, \& Lunt, PK (1992). Predicting personal debt and debt repayment: Psychological, social and economic determinants. Journal of Economic Psychology, 111-134.

Lokadata. (2017). Indonesian Online Shopping Research 2017.Retrieved from Lokadata.com: https://lokadata.beritagar.id/chart/preview/riset- Belanja-online-Indonesia-2017-1502791033

Lührmann, M., Serra-Garcia, M., \& Winter, J. (2014). Teaching teenagers in finance: does it work? Journal of Banking \& Finance, 160-174.

Lusardi, A., Mitchell, O.S., \& Curto, V. (2010). Financial literacy among the young. Journal of Consumer Affairs, 358-380.

Macedo, L.G., Maher, C.G., Latimer, J., Hancock, M.J., Machado, L.A., \& Mcauley, J.H. (2011). Responsiveness of the 24-, 18- and 11-item versions of the Roland Morris Disability Questionnaire. European Spine Journal, 458-463.

Muzafari, S., Mowlaie, S., \& Bahmani, K. (2016). Relationship between Materialism and Financial Risk with the Mediating Role of Emotions and Indebtedness. Journal of Ecophysiology and Occupational Health, 98-102.

Nielsen, L. (2009). Green farm subsidies sponsoring eco-labeling: is the separation of market access and subsidies regulation in WTO law sustainable? Journal of World Trade, 43(6), 1193-1222. Retrieved from http://www.kluwerlawonline.com/productinfo.php? Pub code = TRAD

Olsen, R. (2009). Perceptions of financial risk: axioms and affect. ICFAl Journal of Behavioral Finance, 4.

Ottaviani, C., \& Vandone, D. (2010). impulsivity and household indebtedness: evidence from real life. Journal of Economic Psychology, 754-761.

Pham, T.H., Yap, K., \& Dowling, L.A. (2012). The impact of financial management practices and financial attitudes on the relationship between materialism and compulsive buying. Journal of Economic Psychology, 461-470.

Ponchio, M.C. (2006). The influence of materialism on consumption indebtedness in the context of lowincome consumers from the city of São Paulo. Retrieved from bibliotecadigital: https: // bibliotecadigita I. fgv.br/DSpace/bitstream/handle/10438/2519/142172.pdf

Potrich, A.G., Viera, K.M., \& Mendes-da-Silva, W. (2016). Development of a financial literacy model for university students. Management Research Review, 356-376.

Puranidhi, A.W. (2019, January 10). Most Indebted Millennials. Retrieved from liputan6.com: https://www.liputan6.com/bisnis/read/3867348/millennial-most-owed-generationgenes

Quelch, J.A., \& Jocz, K.E. (2007). Greater Good: How Good Marketing Makes for a Better World. Harvard Business Press, Boston.

Rahayu, A.Y. (2019, 8 29). Millennials in Indonesia have more installments than investments. Retrieved from Merderka.com: https://www.merdeka.com/uang/milenial-di- Indonesia-morehave-installments-than-investment.html

Richins, M.L., \& Dawson, S.A. (1992). Consumer values orientation for materialism and its measurement: Scale development and validation. Journal of Consumer Research, 303-316.

Rudhiwantoro, A. (2018). Important Steps for Millennial Generation towards Financial Freedom through Investment. Journal of Accounting and Finance, 1.

Santos, C.P., \& Fernandes, C.C. (2011). The socialization of consumption and the formation of materialism among adult. Rev. Admin. Mackenzie, 169-203.

Selvaraja, M., \& Abdullah, A. (2019). Psychological factors effects on Propensity towards Indebtedness by applying the Behavioral Economic Theory: Evidence in Malaysia. International Journal of Recent Technology and Engineering, 6. 
Setiawan, K. (2020, February 1). Not smart to manage money, millennials are easily caught in debt. Retrieved from NU Online: https://www.nu.or.id/post/read/116082/tidak-smart-moneymanagement - millennial-easy-entangled- debt

Sevin, N., Temizel, F., \& Sayilir, Ö. (2012). The effects of financial literacy on the borrowing behavior of Turkish financial consumers. International Journal of Consumer Studies, 573-579.

Sugiyono. (2017). Business research methods: Quantitative, qualitative, combined and $R \& D$ approaches. Bandung: Alfabeta.

Supriyatna, I. (2019, September 15). These are three causes of millennial debt, avoid it immediately! Retrieved from Suara.com: https://www.suara.com/bisnis/2019/09/15/130554/i ni-three-causes-millennial-lots-debt-immediately-avoid

Tashandra, N. (2018, 3 22). 80 Percent of Online Shopping Consumers Young People and Women this article has been published on Kompas.com with the title "80 Percent of Online Shopping Consumers Young People and Women", https://lifestyle.kompas.com/read/2018/ 03/22/155001820/80-percent-of-consumers-shopping-online. Retrieved from Kompas.com: https://lifestyle.kompas.com/read/2018/03/22/155001820/80-percent-consumers-shoppingonline-young-people-and-women? Page = all

Xie, Z. (2007). Modeling genetic regulatory networks: A new model for circadian rhythms in Drosophila and investigation of genetic noise in a viral infection process (Doctoral thesis, Lincoln University, 2007). Retrieved from http://hdl.handle.net/10182/31 